\title{
Summary of Compression Testing of U-10Mo
}

\author{
EA Nyberg \\ VV Joshi \\ CA Lavender \\ DE Burkes
}

October 2012

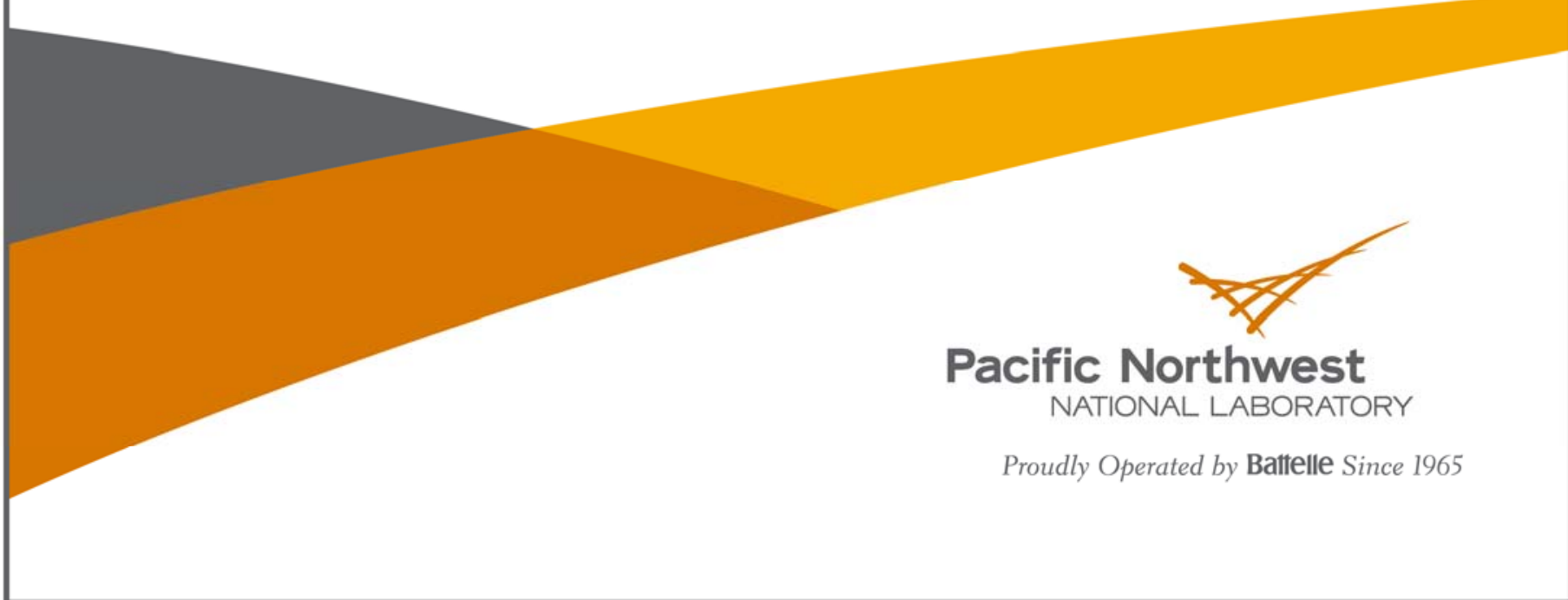




\title{
DISCLAIMER
}

This report was prepared as an account of work sponsored by an agency of the United States Government. Neither the United States Government nor any agency thereof, nor Battelle Memorial Institute, nor any of their employees, makes any warranty, express or implied, or assumes any legal liability or responsibility for the accuracy, completeness, or usefulness of any information, apparatus, product, or process disclosed, or represents that its use would not infringe privately owned rights. Reference herein to any specific commercial product, process, or service by trade name, trademark, manufacturer, or otherwise does not necessarily constitute or imply its endorsement, recommendation, or favoring by the United States Government or any agency thereof, or Battelle Memorial Institute. The views and opinions of authors expressed herein do not necessarily state or reflect those of the United States Government or any agency thereof.

\author{
PACIFIC NORTHWEST NATIONAL LABORATORY \\ operated by \\ BATTELLE \\ for the \\ UNITED STATES DEPARTMENT OF ENERGY \\ under Contract DE-AC05-76RL01830
}

Printed in the United States of America
Available to DOE and DOE contractors from the Office of Scientific and Technical Information,
P.O. Box 62, Oak Ridge, TN 37831-0062;
ph: (865) 576-8401
fax: $(865)$ 576-5728
email: reports@adonis.osti.gov

\begin{abstract}
Available to the public from the National Technical Information Service, U.S. Department of Commerce, 5285 Port Royal Rd., Springfield, VA 22161 ph: (800) 553-6847 fax: $(703) 605-6900$ email: orders@ntis.fedworld.gov online ordering: http://www.ntis.gov/ordering.htm
\end{abstract}

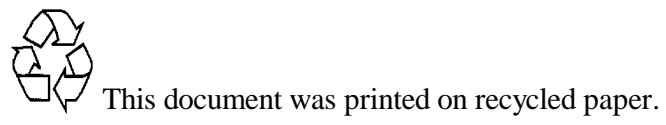




\title{
Summary of Compression Testing of U-10Mo
}

\author{
EA Nyberg \\ VV Joshi \\ CA Lavender \\ DE Burkes
}

October 2012

Prepared for

the U.S. Department of Energy

under Contract DE-AC05-76RL01830

Pacific Northwest National Laboratory

Richland, Washington 99352 



\begin{abstract}
The mechanical properties of depleted uranium alloyed with 10 weight percent molybdenum alloy (U-10Mo) have been evaluated by high-temperature compression testing. Compression testing was conducted at three strain rates over a temperature range of 400 to $800^{\circ} \mathrm{C}$. The results indicate that with increasing test temperature, material flow stress decreases and the material becomes more sensitive to strain rate. In addition, above the eutectoid transformation temperature, the drop in material flow stress is prominent and shows a strain-softening behavior, especially at lower strain rates.
\end{abstract}





\section{Contents}

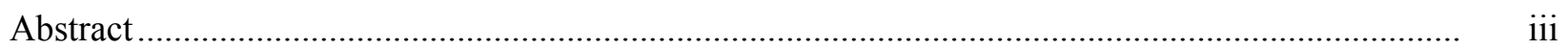

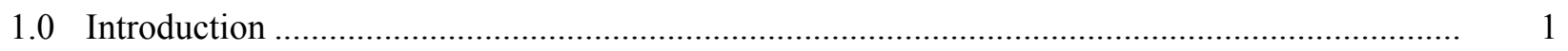

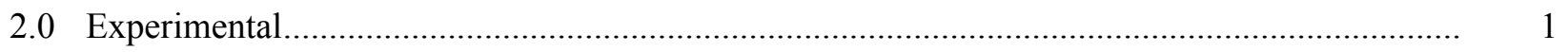

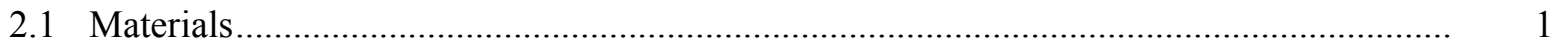

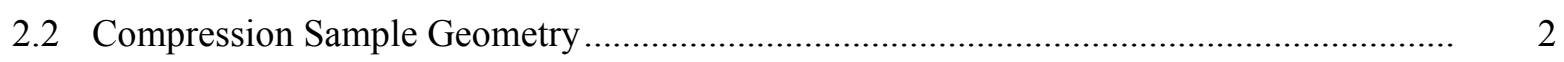

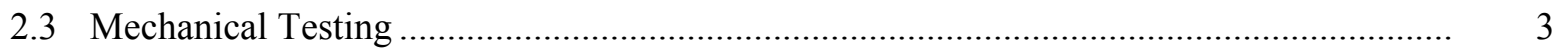

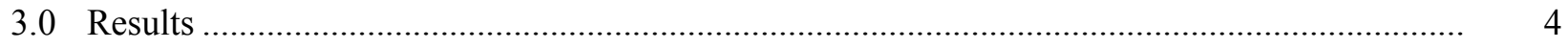

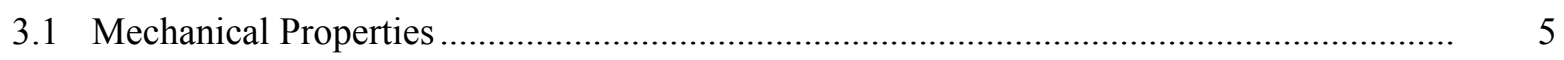

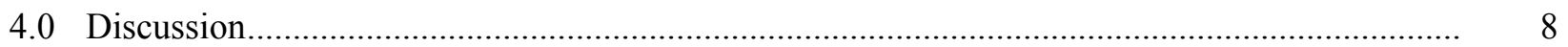

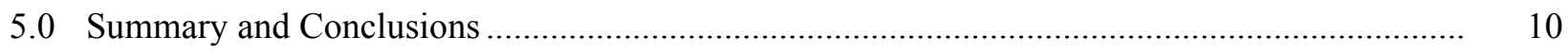

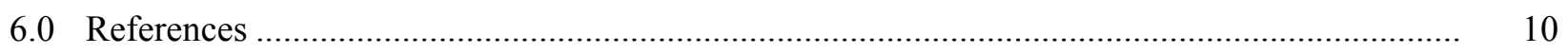

Appendix A - U-10Mo Compression Sample Description......................................................... A.1

Appendix B - U-10Mo Representative Compression Stress-Strain and Strain Rate Sensitivity

Data.

B.1 


\section{Figures}

1 U-Mo Samples Shown Prior to Testing and Inside the Test Fixture ....................................... 2

2 The Pacific Northwest National Laboratory U-Mo Compression Test System, Shown With Its Water-Cooled Furnace and Ar-Purged Chamber With Sample Test Fixture in Place............ 3

3 Stress-Strain Plots Showing the Difference in Engineering Stress and Strain With and Without the Compliance Adjustment for a Cross-Head Velocity of $5 \times 10^{-3} \mathrm{in} / \mathrm{sec}$ at $400^{\circ} \mathrm{C} \ldots \ldots . . \quad 5$

4 Stress-Strain Curves of the U-10Mo for Selected Individual Tests as a Function of Strain

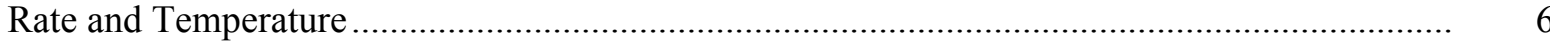

5 Temperature-Dependent True-Stress True-Strain Curves of the U-10Mo Tested at $6.7 \times 10^{-2}$, $6.5 \times 10^{-4}$, and $8.6 \times 10^{-6} \mathrm{~s}^{-1}$

6 The Young's Modulus of U-10Mo Shown vs. Temperature and Strain Rate.

7 The Strain Hardening Exponent and Coefficient for U-Mo10 Were Measured as a Function of Temperature and Strain Rate ................................................................................... 8

8 The Molybdenum-Uranium Binary Phase Diagram ......................................................... 9

9 Molybdenum-Uranium Time, Temperature, and Transformation Curves ............................... 9

\section{Tables}

1 Chemical Composition of the Feedstock Coupon Used for the 0.25-in.-diameter arc-melted pins

2 Test Matrix of U-10Mo Compression Tests Showing the Strain Rate, Temperature, and Number of Samples Tested at Each Condition.

3 Compressive Flow Stress and Strain-Rate Sensitivity With Temperature and Strain Rate for $\mathrm{U}-10 \mathrm{Mo}$

4 Strain Hardening Exponent, $n$, and Strength Coefficient, $K$, for U-10Mo Compression Tests .... 


\subsection{Introduction}

For several years, research to develop alternate fuels for nuclear research and test reactors has been underway to replace high enriched uranium (HEU) fuel with low enriched uranium (LEU) fuel (Burkes et al. 2010a; Snelgrove et al. 1997). To achieve a similar U-235 content with low enriched uranium, given reactor space constraints, a higher bulk density of fuel is needed - necessitating the use of metal alloy fuel. An alloy that offers a good combination of irradiation performance, oxidation resistance, strength, and ductility is required for test-reactor applications. Various uranium alloys have been evaluated for many decades looking at mechanical properties and susceptibility to oxidation (Erickson et al. 1972; Antill and Peakall 1961). Depleted uranium alloyed with $10 \mathrm{wt} \%$ molybdenum (U-10Mo) shows improvement in these regards compared to similar alloys (Burkes et al. 2010a). However, the hot-rolling behavior must be modeled to optimize fabrication of the fuel. The first step in the modeling process is to ascertain accurate mechanical property information at the appropriate conditions. For hot working prediction, in particular, the flow stress must be tested over a range of strain rates and temperatures. Available U-Mo literature contains variable alloy and test conditions (temperatures and strain rates), making precise comparisons between data sets difficult. Although several studies have evaluated the properties of uranium alloys, none have looked specifically at the strain-rate sensitivity or other forminglimit behavior of U-10Mo (Clark et al. 2006; Waldron et al. 1958; Hills et al. 1961; Hills et al. 1964).

To determine the flow stress at conditions that represent hot work of U-10Mo, as-cast samples were tested in compression at temperatures between 400 and $800^{\circ} \mathrm{C}$ and at nominal strain rates between $1 \times 10^{-1}$ and $1 \times 10^{-5} \mathrm{~s}^{-1}$. This report summarizes the results of a series of compression tests of U-10Mo alloy conducted at the Pacific Northwest National Laboratory.

\subsection{Experimental}

\subsection{Materials}

The 0.5 -in.-long compression samples were machined from 1.5 -in.-long by 0.25 -in.-diameter pins that had been arc-melted and cast in copper molds at the Idaho National Laboratory (INL). The feedstock used in the arc melting was in the form of pieces sectioned from a coupon. The coupon was machined from vacuum-induction-melted and then cast plates of $\mathrm{U}-10 \mathrm{Mo}$ melted at $1330^{\circ} \mathrm{C}$, cast into a graphite mold, and homogenized in-mold at $1100^{\circ} \mathrm{C}$ for $4 \mathrm{hr}$. All material processing, other than that performed at INL was conducted at the Y-12 National Security Complex.

The chemical composition of the arc-cast samples was not independently measured; however, the composition of the feedstock coupon was reported (Table 1). 
Table 1. Chemical Composition of the Feedstock Coupon Used for the 0.25 -in.-diameter arc-melted pins

\begin{tabular}{|c|c|c|c|c|c|}
\hline Element & Content & & $\begin{array}{l}\text { mated } \\
\text { ror }\end{array}$ & $\begin{array}{l}\text { Unit of } \\
\text { Measure }\end{array}$ & Comment \\
\hline Mo & 10.1 & \pm & 0.9 & $\mathrm{wt} \%$ & \\
\hline $\mathrm{U}$ & 88.7 & \pm & 0.7 & wt $\%$ & $(99.8 \% 238 \mathrm{U})$ \\
\hline $\mathrm{Al}$ & 74 & \pm & 11 & ppm & \\
\hline $\mathrm{C}$ & 806 & \pm & 65 & ppm & \\
\hline Co & 6.45 & \pm & 0.64 & ppm & \\
\hline $\mathrm{Cu}$ & 23 & \pm & 7 & ppm & \\
\hline $\mathrm{Fe}$ & 289 & \pm & 63 & ppm & \\
\hline $\mathrm{Mn}$ & 22 & \pm & 7 & ppm & \\
\hline $\mathrm{Ni}$ & 43.5 & \pm & 16.3 & ppm & \\
\hline $\mathrm{Si}$ & 371 & \pm & 158 & ppm & \\
\hline $\mathrm{W}$ & 40 & \pm & 11 & ppm & \\
\hline
\end{tabular}

\subsection{Compression Sample Geometry}

An example of the 0.25-in.-diameter test samples is shown in Figure 1a. The diameter was selected based on the availability of Idaho National Laboratory's pin casting mold and Pacific Northwest National Laboratory's test fixture. A length of 0.5 in. was chosen to prevent, or minimize, buckling due to the expected low elastic modulus and work hardening for the U-10Mo at elevated temperatures. Ideally, the sample would be longer to minimize frictional end effects along the length of the specimen and minimize barreling; however, when determining flow stress at relatively high strain, the elastic modulus (tangent modulus) can be so low that the sample buckles and grossly under predicts the flow stress. The 2:1 length-to-diameter ratio was considered the maximum ratio allowable to avoid buckling and still provide the most accurate flow stress possible.

As previously mentioned, no further thermomechanical processing or heat treatments were conducted on the as-cast samples prior to testing. The ends of the right cylinder specimens were examined and any cutting burrs were removed. Samples were measured to evaluate end-to-end perpendicularity; if required, minimal wet sanding was conducted in a glovebox using a jig made specifically for squaring the end surfaces.

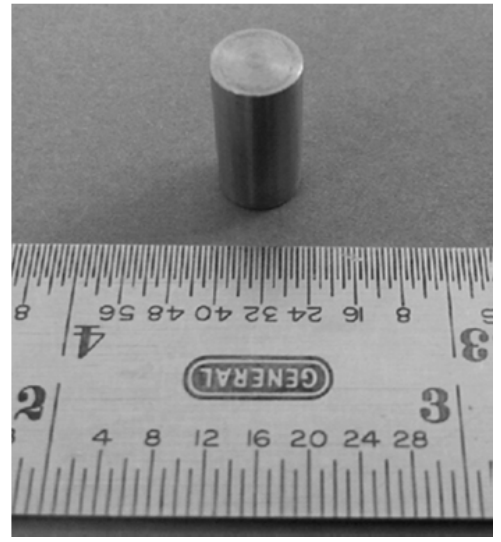

(a)

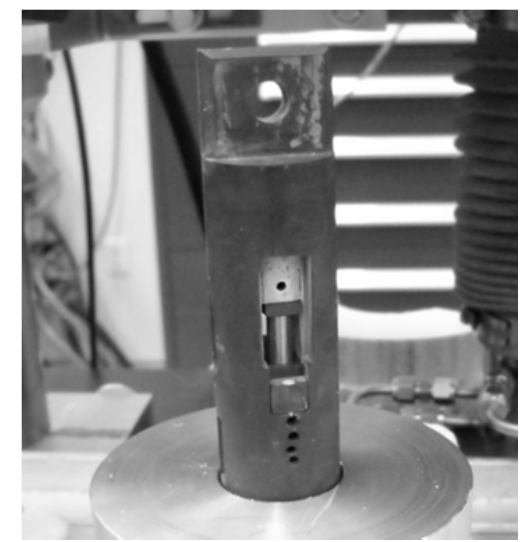

(b)

Figure 1. U-Mo Samples Shown (a) Prior to Testing and (b) Inside the Test Fixture 


\subsection{Mechanical Testing}

Mechanical testing was performed in a servo-hydraulic Instron tensile testing machine using a boxtype furnace with an argon cover-gas atmosphere (Figures $2 a$ and $2 b$ ). Before heating, the furnace was purged at an elevated Ar flow rate (estimated to be five furnace exchanges) over 15 minutes. During testing, a continuous Ar flow flushed oxygen away from the specimen to minimize oxidation (Figure 2c). Evidence of sample oxidation was observed, particularly at temperatures $\geq 600^{\circ} \mathrm{C}$. The test system used (Instron) is based on a servo-hydraulic design integrated with digital control and data collection. A test procedure was written and used as the primary test instruction. ${ }^{1}$

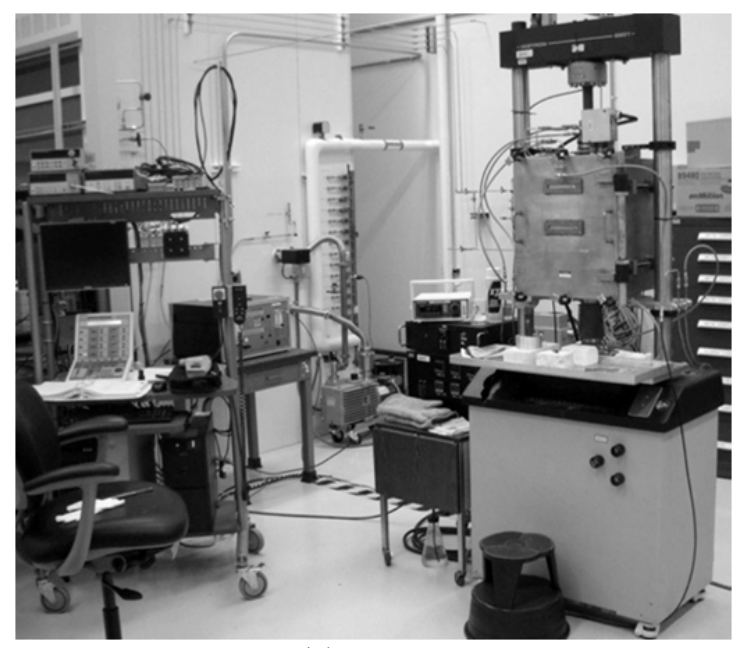

(a)

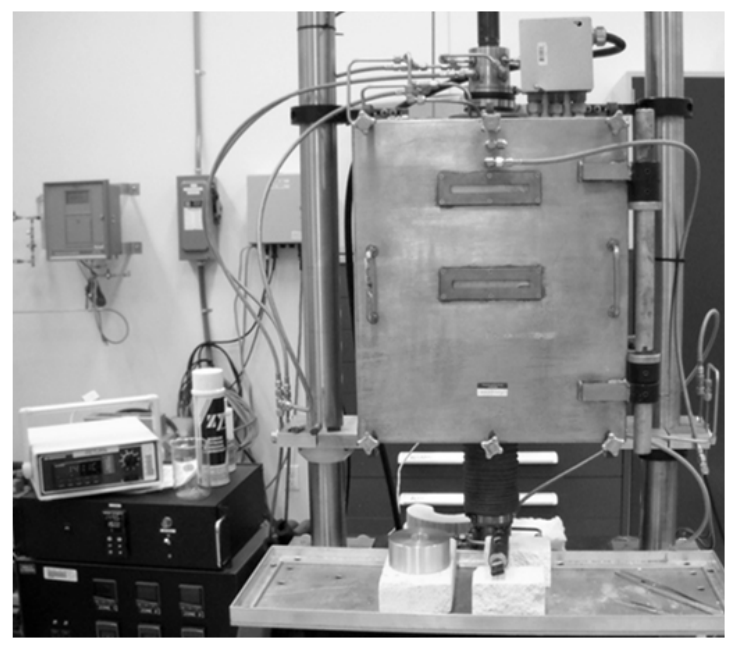

(b)

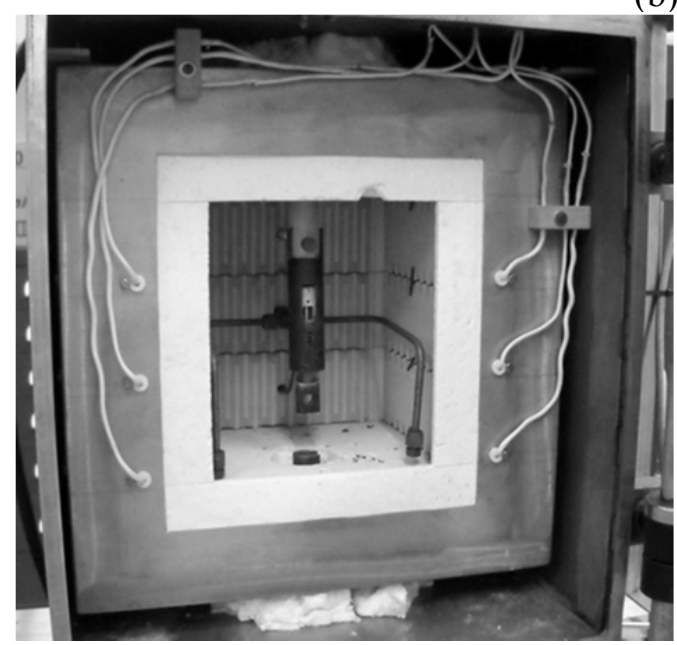

(c)

Figure 2. The (a) Pacific Northwest National Laboratory U-Mo Compression-Test System, Shown With Its (b) Water-Cooled Furnace and (c) Ar-Purged Chamber With Sample Test Fixture in Place.

\footnotetext{
${ }^{1}$ Ermi RM. 2012. “Compression Testing in the 1404 Test Laboratory,” Rev. 1, PNNL test procedure
} 
A custom-designed compression-test system was used. As shown in Figures $1 \mathrm{~b}$ and $2 \mathrm{c}$, the sample is compressed as the fixture is pulled in tension, thereby minimizing the impact of alignment. Boron nitride lubricant was used between the platens and the test samples during the tests.

Heating rates were consistent throughout testing; samples were heated from room temperature to $350^{\circ} \mathrm{C}$ at $10^{\circ} \mathrm{C} / \mathrm{min}$. After holding for $30 \mathrm{~min}$ at this $350^{\circ} \mathrm{C}$, the heat was increased, typically at a rate of $5^{\circ} \mathrm{C} / \mathrm{min}$, to the desired test temperature. Once the test temperature was reached, the sample was allowed to soak for $15 \mathrm{~min}$ prior to compression.

Table 2 shows the matrix used for the 32 tests summarized in this report, which includes testing at 6 temperatures and 3 different strain rates. Appendix A contains a detailed list of all tested samples.

Table 2. Test Matrix of U-10Mo Compression Tests Showing the Strain Rate, Temperature, and Number of Samples Tested at Each Condition.

\begin{tabular}{cccc}
\hline \multicolumn{4}{c}{ Strain Rates } \\
\hline Temperatures & $\begin{array}{c}6.7 \times 10^{-2}\left(\mathrm{~s}^{-1}\right) \\
\text { samples }\end{array}$ & $\begin{array}{c}6.5 \times 10^{-4}\left(\mathrm{~s}^{-1}\right) \\
\text { samples }\end{array}$ & $\begin{array}{c}8.6 \times 10^{-6}\left(\mathrm{~s}^{-1}\right) \\
\text { samples }\end{array}$ \\
\hline $400^{\circ} \mathrm{C}$ & 3 & 3 & 2 \\
$500^{\circ} \mathrm{C}$ & 2 & 3 & 1 \\
$550^{\circ} \mathrm{C}$ & 2 & - & - \\
$600^{\circ} \mathrm{C}$ & 3 & 3 & 1 \\
$700^{\circ} \mathrm{C}$ & 2 & 3 & 1 \\
$800^{\circ} \mathrm{C}$ & 1 & 1 & 1 \\
\hline
\end{tabular}

\subsection{Results}

Due to the test system configuration, the desire to measure flow stress at high strains, and complications associated with the reactivity of the U-10Mo, compression tests were conducted without a strain gauge/extensometer or other methods to evaluate strain/deformation (e.g., digital image correlation). Therefore, compressive load was measured as a function of the cross-head velocity and then used to calculate stress and strain. To increase the accuracy of the stress-strain data, displacements were later adjusted to compensate for the compliance (elasticity) of the testing system. The compliance of the system was determined by conducting compression tests using the test fixture without specimens at representative test temperatures and determining load displacement. To calculate strain, the displacement within the system without a sample as a function of load was subtracted from the actual test data. Figure 3 shows stress-strain plots, with and without compliance compensation, for samples strained with a crosshead velocity of $5 \times 10^{-3} \mathrm{in} / \mathrm{s}$ at $400^{\circ} \mathrm{C}$. Henceforth, all the stress-strain data reported in this report will be compliance adjusted. 


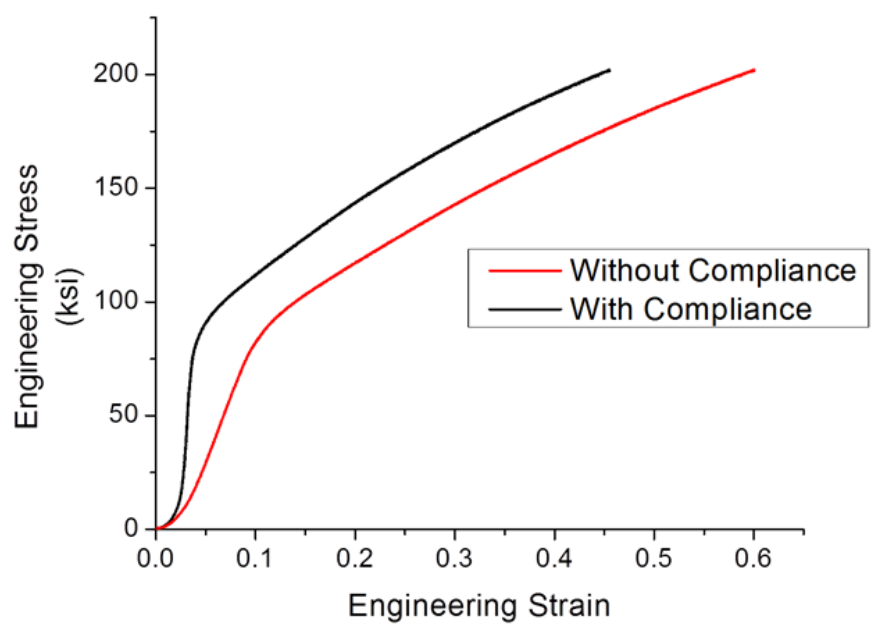

Figure 3. Stress-Strain Plots Showing the Difference in Engineering Stress and Strain With and Without the Compliance Adjustment for a Cross-Head Velocity of $5 \times 10^{-3} \mathrm{in} / \mathrm{sec}$ at $400^{\circ} \mathrm{C}$.

The actual true-strain rates $(\dot{\varepsilon})$ for each test were determined from the slope of true strain versus time and found to be $6.7 \times 10^{-2}, 6.5 \times 10^{-4}$, and $8.6 \times 10^{-6} \mathrm{~s}^{-1}$ for the nominal strain rates of $1 \times 10^{-2}, 1 \times 10^{-3}$, and $1 \times 10^{-5} \mathrm{~s}^{-1}$, respectively. Due to the long testing times, the slowest strain rate tests used a 10 second dataacquisition time interval, unlike the other tests wherein the data was collected at a rate of more than 10 points/s. In addition, the $8.6 \times 10^{-6} \mathrm{~s}^{-1}$ tests were run for a fixed 2-hr period, rather than to a target strain level as done with the faster rates.

The slope of the curve in the elastic region was used to measure the Young's modulus. Three random sections within this region were averaged and used to measure the reported values of the modulus.

For each test, the true flow stress, $\sigma_{\mathrm{f}}$, was determined at a true offset strain of 0.1 . The flow stress and true-stress/true-strain curves for each test were used to calculate strain-rate sensitivity, $m$, strain-hardening exponent, $n$, and strain-hardening coefficient, $K$ (See Equations 1 and 2) (Dieter 2001).

$$
\begin{aligned}
& \sigma=\left.C \dot{\varepsilon}^{m}\right|_{T, \varepsilon} \\
& \sigma=\left.K \varepsilon^{n}\right|_{T, \dot{\varepsilon}}
\end{aligned}
$$

\subsection{Mechanical Properties}

True-stress/true-strain curves for each test condition, under compressive loads, at various strain rates and temperatures are provided in Figure 4. Plots, like those in Figure 4 and Appendix B, were used to determine $n, m$, and $\sigma_{\mathrm{f}}$ (flow stress) which are summarized in Table 3. Flow stress decreased with increasing temperature from a maximum of $125 \mathrm{ksi}$ at $400^{\circ} \mathrm{C}$ to a minimum of $5 \mathrm{ksi}$ at $800^{\circ} \mathrm{C}$. The effect of temperature on flow stress for a given strain rate is plotted in Figure 5. The increase in variation indicates that the U-10Mo exhibits strain-rate sensitivity as a function of temperature. At $400^{\circ} \mathrm{C}$, samples showed no strain-rate sensitivity $(m=0.0)$; however, samples tested above $500^{\circ} \mathrm{C}$ indicated reduced flow stress at lower strain rates. The maximum strain-rate sensitivity, $m=0.22$, was observed at $800^{\circ} \mathrm{C}$. 

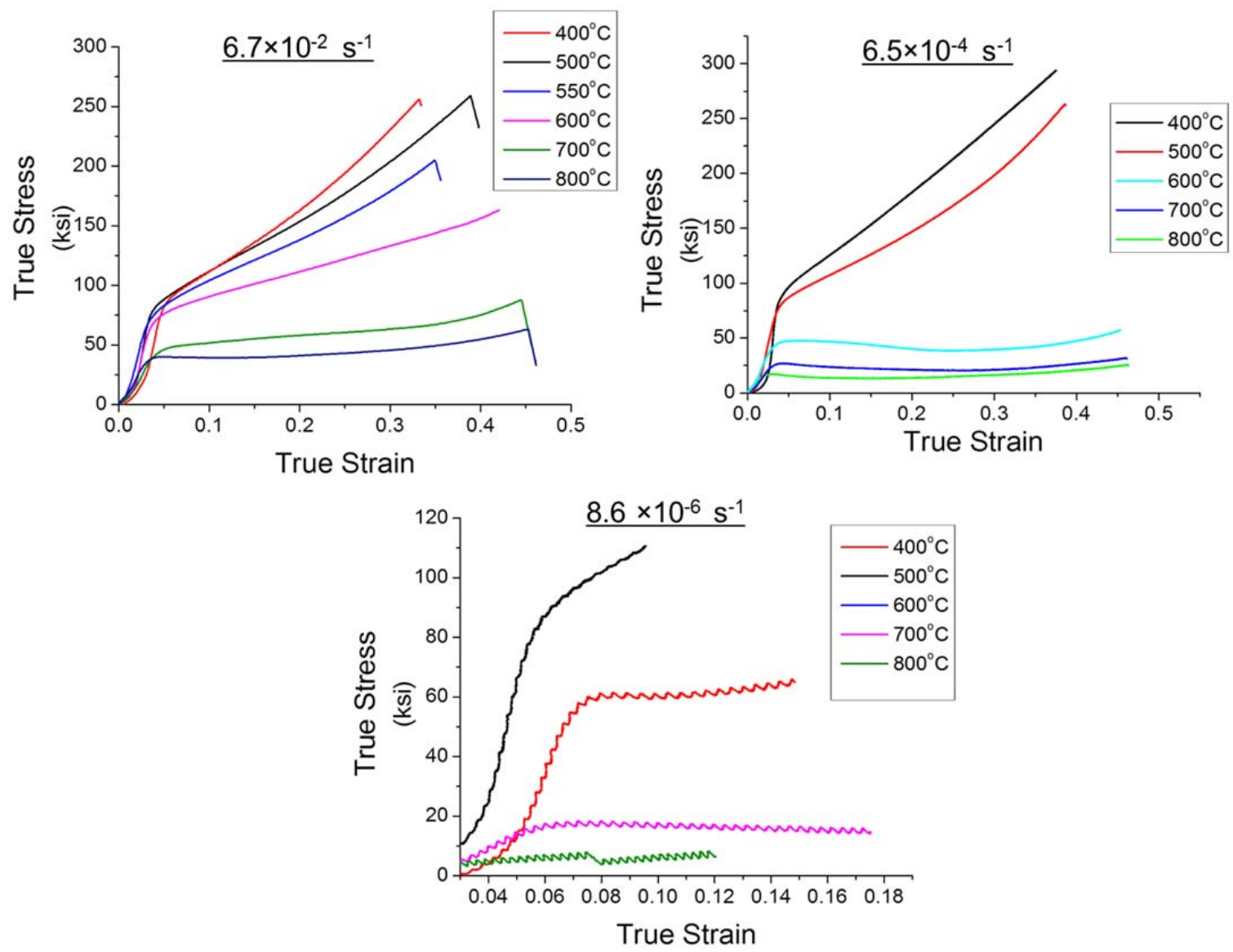

Figure 4. Stress-Strain Curves of the U-10Mo for Selected Individual Tests as a Function of Strain Rate (i.e., $6.7 \times 10^{-2}, 6.5 \times 10^{-4}$ and $8.6 \times 10^{-6} \mathrm{~s}^{-1}$ ) and Temperature

Table 3. Compressive Flow Stress and Strain-Rate Sensitivity With Temperature and Strain Rate for U-10Mo.

\begin{tabular}{ccccc}
\hline & \multicolumn{3}{c}{ Flow Stress at 0.1 Strain, ksi } & \\
\cline { 2 - 4 } Temperature & $6.7 \times 10^{-2} \mathrm{~s}^{-1}$ & $6.5 \times 10^{-4} \mathrm{~s}^{-1}$ & $8.6 \times 10^{-6} \mathrm{~s}^{-1}$ & $\mathrm{~m}$ \\
\hline $400^{\circ} \mathrm{C}$ & 111 & 125 & 112 & 0.00 \\
$500^{\circ} \mathrm{C}$ & 111 & 107 & 60 & 0.07 \\
$600^{\circ} \mathrm{C}$ & 90 & 47 & 17 & 0.18 \\
$700^{\circ} \mathrm{C}$ & 59.2 & 23 & 17 & 0.14 \\
$800^{\circ} \mathrm{C}$ & 39 & 13 & 5 & 0.22 \\
\hline
\end{tabular}




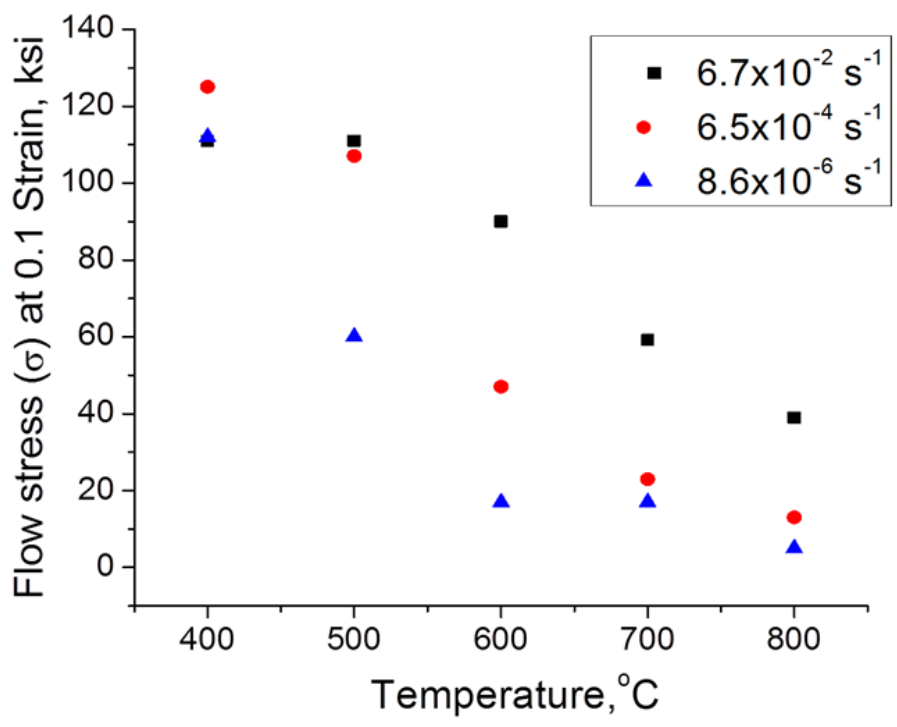

Figure 5. Temperature-Dependent True-Stress True-Strain Curves of the U-10Mo Tested at $6.7 \times 10^{-2}$, $6.5 \times 10^{-4}$, and $8.6 \times 10^{-6} \mathrm{~s}^{-1}$.

To accurately predict elastic modulus, a test method must be used to specifically develop an accurate hysteresis-free curve. However, by compensating for compliance and averaging several elastic regions of the stress-strain curve, an elastic (Young's) modulus of U-10Mo under compressive loads was predicted. The values for elastic modulus for different temperatures and strain rates are presented in Figure 6 . The trend clearly shows that as the temperature increases the Young's modulus decreases. The values are similar to those predicted and measured in previous studies of the mechanical properties of U-10Mo (Waldron et al. 1958).

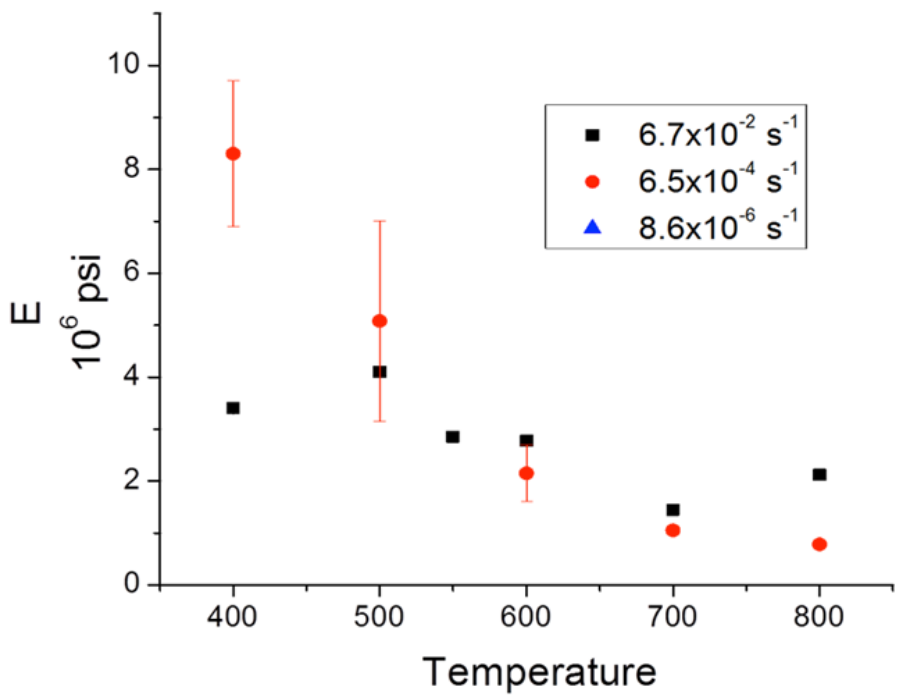

$\left({ }^{\circ} \mathrm{C}\right)$

Figure 6. The Young's Modulus of U-10Mo Shown vs. Temperature and Strain Rate

The strain-hardening exponent, $n$, and strength coefficient, $K$, were calculated using Equation 2 and are shown in Table 4 and plotted as a function of temperature and strain rate in Figure 7. At a strain of 
$6.7 \times 10^{-2} \mathrm{~s}^{-1}$ the material strain hardened $(n>0)$ at all temperatures. However, the $n$ value decreased as the temperature increased. At lower strain rates $\left(8.6 \times 10^{-6} \mathrm{~s}^{-1}\right.$ and $\left.6.5 \times 10^{-4} \mathrm{~s}^{-1}\right)$, it was observed that below $600^{\circ} \mathrm{C}$, the material strain hardened, while above $600^{\circ} \mathrm{C}$ material strain softened $(\mathrm{n}<0)$. A clear transition in the strain-hardening coefficient was observed at $600^{\circ} \mathrm{C}$ in all samples. This trend is consistent with the sudden drop in flow stress observed previously at a temperature greater than $600^{\circ} \mathrm{C}$.

Table 4. Strain-Hardening Exponent, $n$, and Strength Coefficient, $K$, for U-10Mo Compression Tests

\begin{tabular}{ccccccc}
\hline \multirow{2}{*}{$\begin{array}{c}\text { Temp } \\
{ }^{\circ} \mathrm{C}\end{array}$} & \multicolumn{5}{c}{$\mathrm{n}$} & \multicolumn{3}{c}{$\mathrm{K}$} \\
\cline { 2 - 7 } & $6.7 \times 10^{-2} \mathrm{~s}^{-1}$ & $6.5 \times 10^{-4} \mathrm{~s}^{-1}$ & $8.6 \times 10^{-6} \mathrm{~s}^{-1}$ & $6.7 \times 10^{-2} \mathrm{~s}^{-1}$ & $6.5 \times 10^{-4} \mathrm{~s}^{-1}$ & $8.6 \times 10^{-6} \mathrm{~s}^{-1}$ \\
\hline 400 & 1.03 & 0.62 & 0.62 & 801.33 & 505.13 & 475.54 \\
500 & 0.71 & 0.56 & 0.15 & 489.61 & 376.17 & 86.71 \\
550 & 0.82 & -- & -- & 485.86 & -- & -- \\
600 & 0.54 & -0.20 & -1.33 & 256.05 & 29.55 & 1.43 \\
700 & 0.50 & -0.12 & -1.08 & 133.23 & 17.46 & 2.24 \\
800 & 0.63 & 0.17 & -1.61 & 96.46 & 18.93 & 0.10 \\
\hline
\end{tabular}
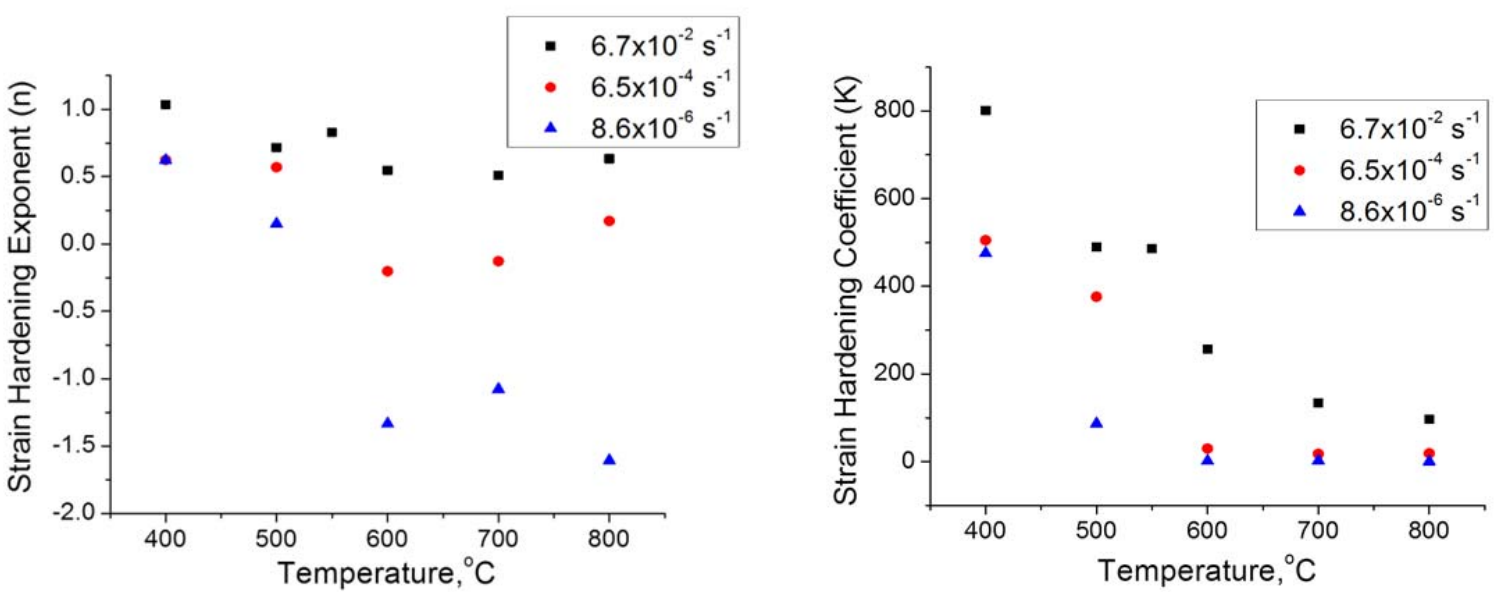

Figure 7. The Strain-Hardening Exponent and Coefficient for U-Mo10 Were Measured as a Function of Temperature and Strain Rate

\subsection{Discussion}

To understand the effect of temperature on the mechanical properties of the samples, it is necessary to observe the phase equilibria (Figure 9) and the Time, Temperature, Transformation (TTT) curves (Figure 10 ) of the U-10Mo system. Earlier work by Burkes et al. (2010a, 2010b, 2010c) determined that hightemperature $\gamma$ phase is retained at room temperature. Therefore, as-received samples can be assumed to have had significant proportions (more than 90 percent) of this high-temperature $\gamma$ phase. Further, Figure 10 shows that the time required to transform $\gamma$ into $\alpha$ phase is very sluggish. Hence, the time required to equilibrate the samples at 400 and $500^{\circ} \mathrm{C}$ was insufficient to transform the $\gamma$ phase completely into $\alpha$ phase. The tests may have been conducted with significant $\gamma$ structure. Similar test results were observed at 400 and $500^{\circ} \mathrm{C}$. 

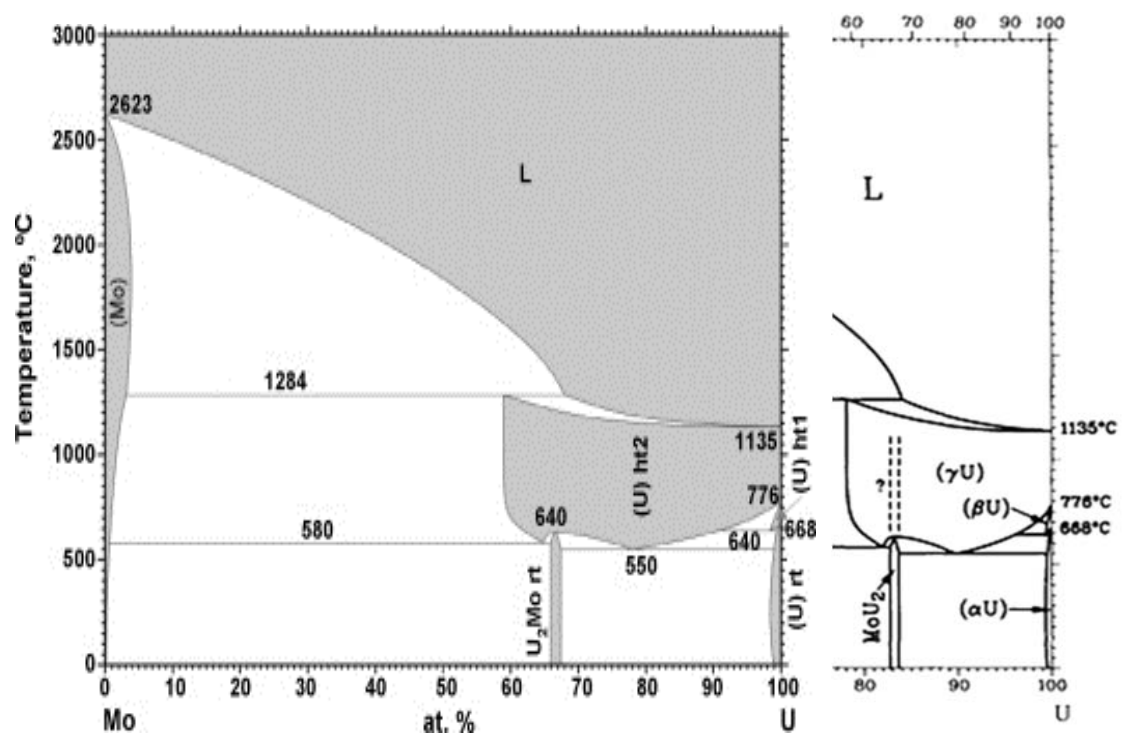

Figure 8. The Molybdenum-Uranium Binary Phase Diagram

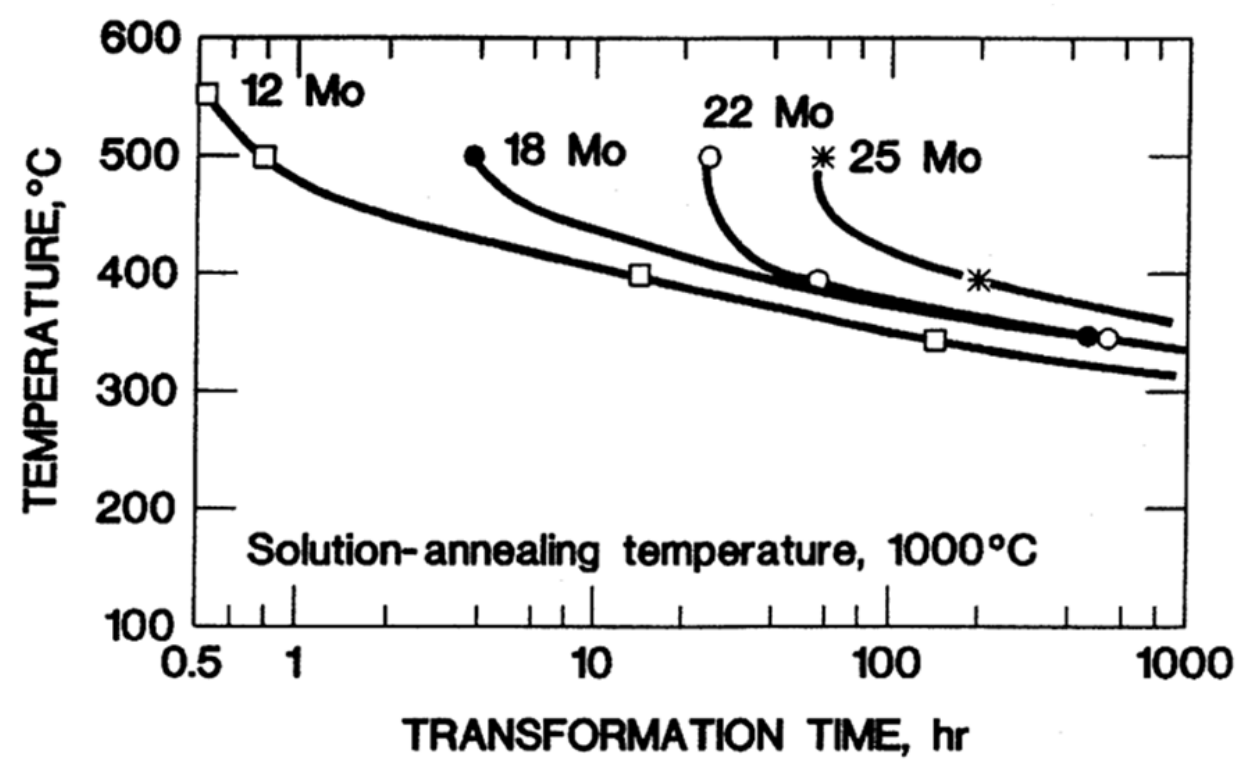

Figure 9. Molybdenum-Uranium Time, Temperature, and Transformation Curves

The difference in the mechanical properties is significant for those samples tested above the eutectoid temperatures wherein the stress-strain response, flow stress, strain hardening exponent and strain hardening coefficient drop drastically at 600 and $700^{\circ} \mathrm{C}$, but slightly increase at $800^{\circ} \mathrm{C}$, especially at high strain rates (Figure 4-7). The variation in properties is within the experimental error range; however, because the tests at 400 and $500^{\circ} \mathrm{C}$ contained significant amounts of $\gamma$ phase, a linear relationship in properties would be expected in all tests. One possible explanation for the property variation is the 
shifting of the chemistry into either a pro-eutectoid or hyper-eutectoid region, forming a quantity of phases of lower strength than the $\gamma$ matrix.

To further the understanding of the U-10Mo system and its behavior at elevated temperatures, it is vital to study, in-depth, the effect of heat treatment on the phase transformation as a function of time and temperature. High-temperature x-ray diffraction tests would prove quite beneficial. Nonetheless, the data presented in this work serves as a starting point for modeling and prediction of the U-10Mo forming processes.

\subsection{Summary and Conclusions}

This work evaluated the effect of temperature on the mechanical properties of U-10Mo under compression. The data generated will be beneficial to successfully modeling the rolling and forming process of the alloy. The following trends were observed:

- An increase in temperature caused a drop in the flow stress.

- Above the eutectoid transformation, the drop in the flow stress was prominent and showed a strainsoftening behavior, especially at lower strain rates of testing.

- As the test temperature increased, the material became increasingly strain-rate sensitive.

To further the understanding of the effect of temperature on mechanical properties, detailed characterization of the U-10Mo at temperatures between 400 and $800^{\circ} \mathrm{C}$ needs to be conducted including:

- Effect of time and temperature on the transformation. High-temperature x-ray diffraction is needed to better understand the phases present when testing (or hot working).

- Effect of hot deformation temperature on the recrystallization behavior and final microstructure.

- Effect of stress at elevated temperature on the U-10Mo phase transformations.

Additional sample testing is planned within the existing temperature-strain-rate test matrix for those combinations where only single tests were conducted.

\subsection{References}

Burkes DE, R Prabhakaran, T Hartmann, JF Jue, and FJ Rice. 2010a. "Properties of DU-10 wt\% Mo alloys subjected to various post-rolling heat treatments," Nuclear Engineering and Design 240:13321339.

Snelgrove JL, GL Hofman, MK Meyer, CL Trybus, and TC Wiencek. 1997. "Development of veryhigh-density low-enriched-uranium fuels," Nuclear Engineering and Design 178:119-126.

Erickson WC, GE Jaynes, DJ Sandstrom, R Seegmiller, and JM Taub. 1972. "Evaluation of Uranium Alloys,” LA-5002, UC-25, Los Alamos Scientific Laboratory, University of California, 
Antill JE and KA Peakall. 1961. "Oxidation of Uranium Alloys in Carbon Dioxide and Air," J. of Less Common Metals, (3):239-246.

Clark CR, JF Jue, GA Moore, NP Hallinan, BH Park. 2006. “Update on Monolithic Fuel Fabrication Methods," Proceedings of the RERTR International Meeting, Cape Town, South Africa.

Waldron MB, RC Burnett, and SF Pugh 1958. The mechanical properties of uranium-molybdenum alloys. AERE-M/B-2554.

Hills RF, BR Butcher and JA Heywood. 1961. "A study on the effect of cooling rate on the decomposition of the $\gamma$-phase in uranium-low molybdenum alloys," Journal of The Less Common Metals, 3:55-169.

Hills RF, BR Butcher, and BW Howlett. 1964. "The mechanical properties of quenched uraniummolybdenum alloys, Part I: Tensile tests on polycrystalline specimens," J. of Nuclear Materials, 11, $2: 149-162$.

Dieter GE. 2001. "The Tension Test," in Mechanical Metallurgy, pp 275-324, McGraw Hill Publications Limited, United Kingdom.

Burkes DE, T Hartmann, R Prabhakaran, J Jue. 2010b. "Microstructural characteristics of DU-xMo alloys with $\mathrm{x}=7-12$ wt\%," J. All. \& Comp., 479[1-2].

Burkes DE, CA Papesch, AP Maddison, T Hartmann, FJ Rice. 2010c. "Thermo-physical properties of DU-10 wt.\% Mo alloys," J. Nucl. Mat., 403[2]. 



\section{Appendix A}

\section{U-10Mo Compression Sample Description}





\section{Appendix A}

\section{U-10Mo Compression Sample Description}

\begin{tabular}{|c|c|c|c|c|c|c|c|c|}
\hline Test \# & Sample \# & Pin ID & Slug \# & $\begin{array}{l}\text { Labeled wt. } \\
\text { (grams) }\end{array}$ & $\begin{array}{l}\text { Measured wt. } \\
\text { (grams) }\end{array}$ & $\begin{array}{c}\text { Temp. } \\
\left({ }^{\circ} \mathrm{C}\right)\end{array}$ & $\begin{array}{c}\text { Strain Rate } \\
\left(\sec ^{-1}\right)\end{array}$ & Date \\
\hline 1 & 1 & Pin A & Slug 1 & 6.794 & 6.7887 & 400 & 1E-03 & $6 / 4 / 2012$ \\
\hline 2 & 4 & Pin $B$ & Slug 2 & 6.746 & 6.7446 & 400 & $1 \mathrm{E}-03$ & $6 / 5 / 2012$ \\
\hline 3 & 6 & Pin C & Slug 2 & 6.873 & 6.8849 & 400 & 1E-03 & $6 / 5 / 2012$ \\
\hline 4 & 13 & Pin G & Slug 1 & 6.782 & 6.7787 & 700 & $1 \mathrm{E}-03$ & $6 / 5 / 2012$ \\
\hline 5 & 16 & Pin J & Slug 1 & 6.813 & 6.8110 & 700 & 1E-03 & $6 / 6 / 2012$ \\
\hline 6 & 2 & Pin A & Slug 2 & 6.921 & 6.9178 & 500 & $1 \mathrm{E}-03$ & $6 / 7 / 2012$ \\
\hline 7 & 3 & Pin B & Slug 1 & 6.930 & 6.9272 & 500 & $1 \mathrm{E}-03$ & $6 / 7 / 2012$ \\
\hline 8 & 5 & Pin C & Slug 1 & 6.880 & 6.8856 & 700 & 1E-03 & $6 / 11 / 2012$ \\
\hline 9 & 8 & Pin D & Slug 2 & 6.938 & 6.9451 & 500 & $1 \mathrm{E}-03$ & $6 / 12 / 2012$ \\
\hline 10 & 9 & Pin $E$ & Slug 1 & 6.653 & 6.6552 & 600 & $1 \mathrm{E}-03$ & $6 / 12 / 2012$ \\
\hline 11 & 10 & Pin $E$ & Slug 2 & 6.824 & 6.8224 & 800 & $1 \mathrm{E}-03$ & $6 / 13 / 2012$ \\
\hline 12 & 11 & Pin $F$ & Slug 1 & 6.924 & 6.9058 & 600 & 1E-03 & $6 / 14 / 2012$ \\
\hline 13 & 12 & Pin $\mathrm{F}$ & Slug 2 & 6.835 & 6.8389 & 600 & 1E-03 & $6 / 14 / 2012$ \\
\hline 14 & 14 & Pin $\mathrm{H}$ & Slug 1 & 6.739 & 6.7427 & 400 & $1 \mathrm{E}-01$ & $6 / 20 / 2012$ \\
\hline 15 & 15 & Pin I & Slug 1 & 6.722 & 6.7153 & 500 & $1 \mathrm{E}-01$ & $6 / 25 / 2012$ \\
\hline 16 & 19 & Pin M & Slug 1 & 6.952 & 6.5968 & 600 & $1 \mathrm{E}-01$ & $6 / 26 / 2012$ \\
\hline 17 & 7 & Pin D & Slug 1 & 6.734 & 6.7310 & 550 & $1 \mathrm{E}-01$ & $6 / 27 / 2012$ \\
\hline 18 & 17 & Pin $K$ & Slug 1 & 6.701 & 6.7103 & 600 & $1 \mathrm{E}-01$ & $6 / 28 / 2012$ \\
\hline 19 & 18 & Pin L & Slug 1 & 7.082 & 7.0854 & 600 & 1.0 & $6 / 29 / 2012$ \\
\hline 20 & 20 & Pin S & Slug 1 & 6.790 & 6.8050 & 400 & $1 \mathrm{E}-01$ & $8 / 14 / 2012$ \\
\hline 21 & 21 & Pin S & Slug 2 & 6.829 & 6.8318 & 500 & 1E-01 & $8 / 15 / 2012$ \\
\hline 22 & 22 & Pin T & Slug 1 & 6.781 & 6.7926 & 550 & $1 \mathrm{E}-01$ & $8 / 15 / 2012$ \\
\hline 23 & 23 & Pin T & Slug 2 & 6.814 & 6.8296 & 600 & $1 \mathrm{E}-01$ & $8 / 16 / 2012$ \\
\hline 24 & 24 & Pin U & Slug 1 & 6.808 & 6.8233 & 700 & $1 \mathrm{E}-01$ & $8 / 20 / 2012$ \\
\hline 25 & 25 & Pin U & Slug 2 & 6.863 & 6.8788 & 400 & $1 \mathrm{E}-01$ & $8 / 21 / 2012$ \\
\hline 26 & 26 & Pin V & Slug 1 & 6.785 & 6.8034 & 700 & 1E-01 & $8 / 21 / 2012$ \\
\hline 27 & 27 & Pin V & Slug 2 & 6.809 & 6.8178 & 400 & $1 \mathrm{E}-05$ & $8 / 22 / 2012$ \\
\hline 28 & 28 & Pin W & Slug 1 & 6.779 & 6.7881 & 400 & $1 \mathrm{E}-05$ & $8 / 23 / 2012$ \\
\hline 29 & 29 & Pin W & Slug 2 & 6.819 & 6.8301 & 500 & $1 \mathrm{E}-05$ & $8 / 24 / 2012$ \\
\hline 30 & 30 & Pin $X$ & Slug 1 & 6.776 & 6.7923 & 600 & $1 \mathrm{E}-05$ & $8 / 28 / 2012$ \\
\hline 31 & 31 & Pin $X$ & Slug 2 & 6.870 & 6.8599 & 700 & $1 \mathrm{E}-05$ & $8 / 29 / 2012$ \\
\hline 32 & 32 & Pin $Y$ & Slug 1 & 6.740 & 6.7470 & 800 & $1 \mathrm{E}-01$ & $8 / 30 / 2012$ \\
\hline 33 & 33 & Pin $Y$ & Slug 2 & 6.833 & 6.8466 & 800 & 1E-05 & $8 / 31 / 2012$ \\
\hline
\end{tabular}

*NOTE: Sample 19 data was not analyzed. 

Appendix B

U-10Mo Representative Compression Stress-Strain and Strain-Rate Sensitivity Data 



\section{Appendix B}

\section{U-10Mo Representative Compression Stress-Strain and Strain-Rate Sensitivity Data}
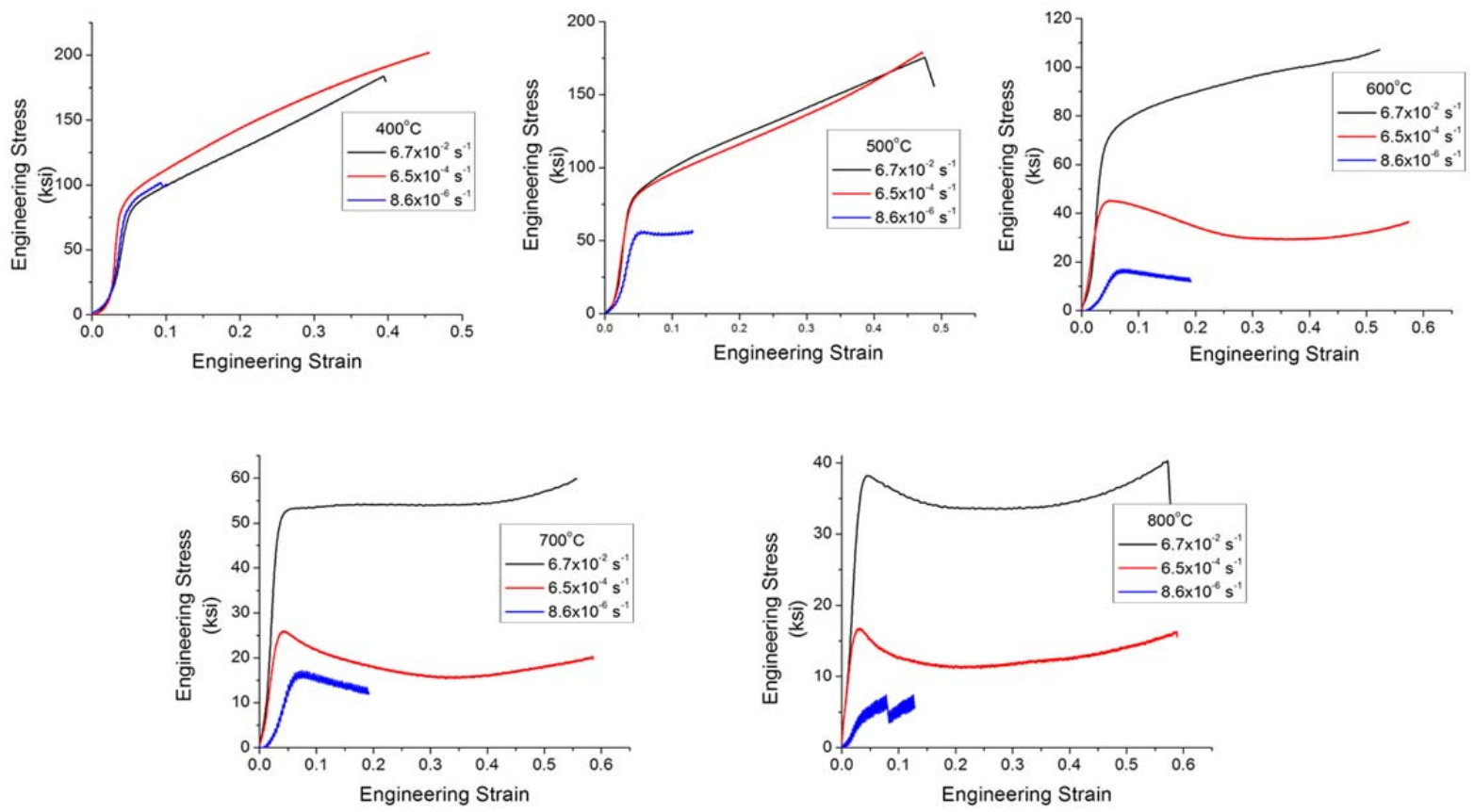

Figure B.1. Stress-Strain Curves of the U-10 Mo Samples Tested As a Function of Strain Rate $6.7 \times 10^{-2}$, $6.5 \times 10^{-4}$, and $8.6 \times 10^{-6} \mathrm{~s}^{-1}$ at Constant Temperatures Ranging From 400 to $800^{\circ} \mathrm{C}$.

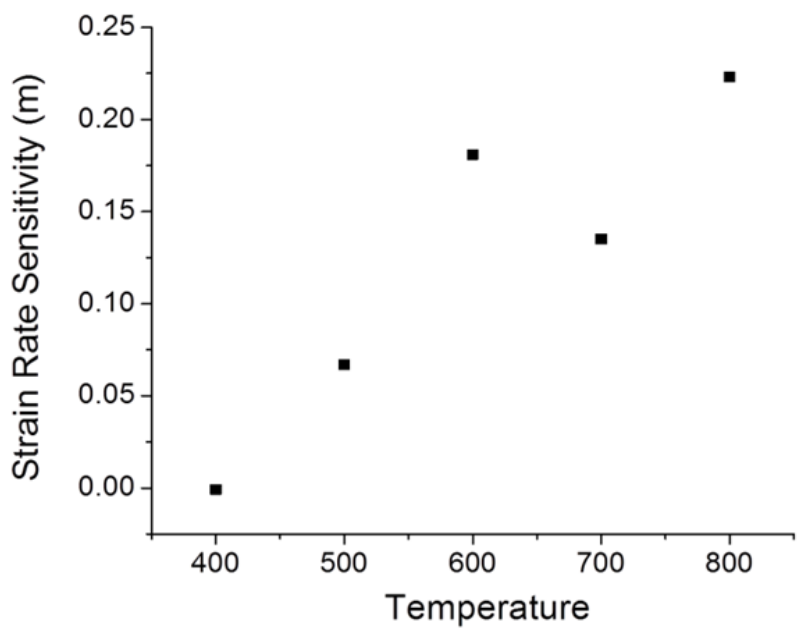

$\left({ }^{\circ} \mathrm{C}\right)$

Figure B.2. U-10Mo Strain-Rate Sensitivity as a Function of Temperature 

PNNL-21932

\section{Distribution}

No. of

Copies

2 Department of Energy National Nuclear Security Administration

Global Threat Reduction Initiative

1000 Independence Ave.

Washington, DC 20002

Mr. Christopher Landers

Dr. Natraj Iyer

5 Idaho National Laboratory

P.O. Box 1625

Idaho Falls, ID 83415

Mr. Jason Schulthess

Dr. Mitchell Meyer

Mr. Glenn Moore

Dr. Barry Rabin

Dr. Dennis Keiser

1 Argonne National Laboratory

9700 S Cass Ave.

Argonne, IL 60439

Dr. John Stevens
No. of

\section{Copies}

\section{$4 \quad$ Local Distribution}

Pacific Northwest National Laboratory

Eric Nyberg

K2-03

Vineet Joshi

$\mathrm{K} 2-03$

Curt Lavender

K2-03

Douglas Burkes

K8-34

Dean Paxton

(PDF)

Chad Painter 




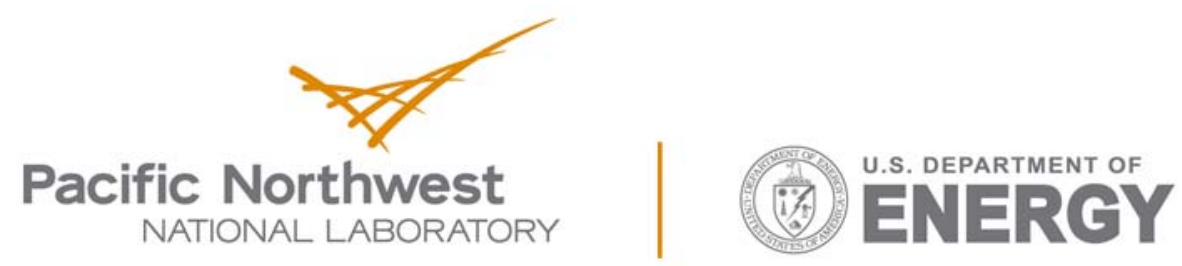

Proudly Operated by Battelle Since 1965

902 Battelle Boulevard

P.O. Box 999

Richland, WA 99352

1-888-375-PNNL (7665)

www.pnnl.gov 